\title{
Monoclonal antibody G250 targeting CA IX: Binding specificity, internalization and therapeutic effects in a non-renal cancer model
}

\author{
MIRIAM ZATOVICOVA ${ }^{1}$, LENKA JELENSKA ${ }^{1}$, ALZBETA HULIKOVA ${ }^{1}$, PETER DITTE ${ }^{1}$, \\ ZUZANA DITTE $^{1}$, LUCIA CSADEROVA ${ }^{1}$, ELISKA SVASTOVA ${ }^{1}$, WOLFGANG SCHMALIX ${ }^{2}$, \\ VOLKER BOETTGER $^{2}$, PAUL BEVAN ${ }^{2}$, JAROMIR PASTOREK ${ }^{1}$ and SILVIA PASTOREKOVA ${ }^{1}$ \\ ${ }^{1}$ Department of Molecular Medicine, Institute of Virology, Slovak Academy of Sciences, \\ 84505 Bratislava, Slovakia; ${ }^{2}$ WILEX AG, 81675 Munich, Germany
}

Received July 9, 2014; Accepted August 20, 2014

DOI: $10.3892 /$ ijo.2014.2658

\begin{abstract}
G250 (Girentuximab) is a chimeric IgG1 monoclonal antibody (MAb) currently being evaluated as an immunotherapy for kidney cancer. It targets carbonic anhydrase protein (CA IX), a transmembrane carbonic anhydrase (CA) isoform, which is regulated by VHL/HIF pathway and hence expressed in the majority of renal cell carcinomas (RCCs) as well as in hypoxic non-RCC tumours. $\mathrm{CA}$ IX functions in $\mathrm{pH}$ regulation and cell migration/invasion, and supports tumour cell survival in hypoxia and/or acidosis. It contains a highly active extracellular catalytic domain (CA) extended $\mathrm{N}$-terminally with a proteoglycan-like region and C-terminally with short transmembrane and intracellular regions. Here we characterize the binding and internalization properties of $\mathrm{G} 250$, as well as its therapeutic effects in animal model, and discuss the impact of G250-mediated immunotherapy in non-RCC tumours. We demonstrated that G250 MAb recognizes a conformational epitope in the CA domain, detects the soluble CA IX ectodomain (ECD), but not the splicing variant, and does not cross-react with CA I, II, and XII isoforms. We showed that G250 internalizes via
\end{abstract}

Correspondence to: Professor Silvia Pastorekova, Department of Molecular Medicine, Institute of Virology, Slovak Academy of Sciences, Dubravska cesta 9, 84505 Bratislava, Slovakia

E-mail: silvia.pastorekova@savba.sk

Abbreviations: ADCC, antibody-dependent cell-mediated cytotoxicity; AS, alternative splicing; CA IX, carbonic anhydrase protein; CA9, human carbonic anhydrase gene; Car9, rodent carbonic anhydrase gene; CAI, carbonic anhydrase inhibitor; ECD, ectodomain; HIF, hypoxia inducible factor; IL-1, interleukin-1; IFN, interferon; MAb, monoclonal antibody; PKA, protein kinase A; RCC, renal cell carcinoma; VHL, von Hippel Lindau

Key words: G250 monoclonal antibody, Girentuximab, carbonic anhydrase IX, hypoxia, immunotherapy, internalization clathrin-coated vesicles, escapes degradation in lysosomes and enters the recycling pathway via the perinuclear compartment. This results in long intracellular persistence and enables consecutive internalization cycles. Moreover, the recycled antibody maintains an intact Fc portion potentially capable of continuous induction of antibody-dependent cell-mediated cytotoxicity (ADCC) response, thus explaining its therapeutic efficacy. Finally, we showed that G250 treatment is effective against HT-29 colorectal carcinoma xenografts that differ from RCC by more heterogeneous, hypoxia-related expression of CA IX. These results suggest potential therapeutic usefulness of the G250 MAb in non-RCC tumours.

\section{Introduction}

Carbonic anhydrase (CA) is a ubiquitous enzyme of fundamental physiological importance. As a catalyst of the reversible inter-conversion between carbon dioxide and carbonic acid (i.e., bicarbonate and proton), it facilitates many biological processes dependent on intensive ion transport, acid-base balance and biosynthetic reactions. The human body contains 15 different CA isoforms mostly expressed in differentiated tissues, among which carbonic anhydrase protein (CA IX) plays a special role as an active component of the tumour phenotype (1).

CA IX possesses several attributes that support its relevance for cancer biology: i) it is present in only few normal tissues, namely in gastrointestinal epithelia (2); ii) it is expressed in a broad spectrum of tumours, mostly carcinomas (3); iii) its expression is associated with von Hippel Lindau (VHL) inactivation that occurs in a high percentage of renal cell carcinomas (RCCs) (4); iv) it is linked to hypoxia and associated with an aggressive phenotype of various non-RCC tumours (5); v) it is strongly activated on the transcriptional level by hypoxia inducible factor (HIF) (predominantly HIF-1 isoform) via the HRE localized next to the transcription initiation site (6); vi) it is induced by hypoxia at the functional level $(7,8)$; vii) it is involved in signal transduction to the PI3K/Akt pathway and from the hypoxia-activated protein kinase A (PKA) $(8,9)$; viii) it plays an active role in tumour biology as a component 
of pH-regulating machinery that protects tumour cells from stress induced by hypoxia and oncogenic metabolism, and thereby contributes to tumour cell survival and treatment resistance (10-12); ix) it also facilitates cell dissociation, adhesion and migration/invasion (13-15); $\mathrm{x}$ ) it is exposed on the cell surface with its catalytic domain and N-terminal proteoglycan region facing the extracellular space and thus being accessible for ectodomain (ECD)-specific antibodies and inhibitors of catalytic activity $(7,16-18)$; $x i)$ it is a highly stable protein that can be shed in a metalloproteinase-dependent manner (19-21); and xii) there are several monoclonal antibodies, which are specific for different domains of CA IX with excellent detection and anticancer properties, and promising selective inhibitors of CA IX enzyme activity are also under development (17,22-28).

CA IX exhibits particularly frequent, strong and diffuse expression in clear cell renal cell carcinomas (ccRCC). These tumours usually grow from lesion with mutations/deletions of the VHL tumour suppressor gene that lead to functional inactivation of the corresponding protein (29). VHL protein (pVHL) is a component of an E3 ligase complex responsible for the normoxic degradation of hydroxylated HIF- $\alpha$ subunits and subsequent inhibition of HIF-mediated responses. Inactivation of pVHL results in a constitutive activation of the HIF pathway and overexpression of the HIF targets, including CA IX $(4,6,30,31)$. However, VHL-defective RCC tumours show a shift from HIF-1 $\alpha$ toward HIF- $2 \alpha$ phenotype in the later stages of cancer progression and therefore expression of CA IX (and other HIF-1 targets) decreases (32). This is the reason for the association of decreased CA IX expression with poor prognosis of RCC patients, although the cut-off value of $85 \%$ of positive cells suggests that the CA IX level may still be high enough to achieve good therapeutic targeting (33). Moreover, expression of CA IX can be further increased by treatment with IL-2 or interferon (IFN)- $\gamma$, thus offering a strategy for enrichment of the target density for the purpose of immunotherapy $(34,35)$.

The situation is different in non-RCC tumours, which are not affected by VHL mutations. Here, the level and distribution of CA IX correlate primarily with the presence of microenvironmental hypoxia that results in stabilization and activation of the HIF- $\alpha$ subunits (6). Indeed, CA IX is often detected in perinecrotic areas and in areas more distant from perfused vasculature and thus its expression is much more variable (from focal to diffuse) and heterogeneous (from weak to strong) than in RCC. This might complicate the immunotherapeutic targeting of such tumours, although earlier studies in mouse models indicate that this is not the case $(17,36)$.

G250 monoclonal antibody (MAb) has been raised against an RCC-associated antigen named G250, which was later proven to be identical to CA IX (also called MN) $(22,37,38)$. The chimeric version of the antibody, cG250, functions principally via antibody-dependent cell-cytotoxicity (ADCC). In Phase II clinical studies in patients with metastatic RCC it showed excellent accumulation in RCC, both primary and metastatic, and increased median survival and overall survival rates (39-42). The Phase I/II study of the combination therapy of cG250 with low dose IFN- $\alpha$ indicated that it was safe, well-tolerated and with clinical benefit for patients with progressive metastatic RCC (43). The Phase III ARISER study with cG250 monotherapy as an adjuvant treatment of nephrectomized ccRCC patients who are at high-risk of disease recurrence, showed that subjects with a high tumour CA IX score have a significantly improved disease-free survival (44).

Successful clinical development of cG250 in RCC and significance of CA IX as an intrinsic component of tumour hypoxia in a broad spectrum of cancers promoted interest in the possible application of a similar immunotherapeutic approach in non-RCC tumours. However, before initiation of clinical studies, it was important to better characterize the binding properties of cG250 to CA IX antigen in different physiological conditions, its kinetics and mode of internalization, fate and integrity of the internalized antibody, and in vivo therapeutic effects of $\mathrm{cG} 250$ in a non-RCC model. This report summarizes the results of such characterization, which indicate that the therapeutic targeting of non-RCC tumours with cG250 is feasible.

\section{Materials and methods}

Antibodies, inhibitors and recombinant fusion proteins. The parental mouse MAb mG250 (IgG2a) and its human-mouse IgG1 chimeric version cG250 (Rencarex/Girentuximab) were provided by WILEXAG. The human CAIXPG domain-specific monoclonal antibodies M75 and IV/18, and CA domain-specific monoclonal antibodies VII/20, V/12 and V/10 were described previously (24). The mouse CA IX-specific MAb AM4 was also described earlier (45). Homosulfanilamide, a CA inhibitor with an IC50 of $0.1 \mathrm{mM}$, determined as inhibition of extracellular acidification mediated by CA IX in cell culture (7), was provided by Professor Claudiu T. Supuran (University of Florence). GST-CA (GST fused to full-length human CA IX protein) and GST-Car9 (GST fused to full-length mouse CA IX protein) were described before $(24,45)$.

Cells. For the experiments described in this report, we used MDCK canine kidney cells permanently transfected with the full-length human carbonic anhydrase ( $C A 9)$ cDNA in the pSG5C plasmid (MDCK-CA9) or with plasmids derived thereof encoding a CA domain deletion variant (MDCK- $\triangle \mathrm{CA}$ ), a PG domain deletion variant (MDCK- $\triangle \mathrm{PG}$ ) and a human alternatively spliced protein truncated in the $\mathrm{C}$-terminal part of the CA domain (MDCK-hAS). Mock-transfected cells (MDCK-neo) were used as a negative control. The CGL3 tumourigenic cell line (HeLa x fibroblast hybrid) with high normoxic expression of CA IX and moderate induction by hypoxia (20) was kindly provided by Professor Eric J. Stanbridge (University of California, Irvine). Human HT-29 colorectal carcinoma cells (ATCC), which express CA IX at high endogenous level, were used for in vivo experiments. The cells were routinely cultured in DMEM with $10 \%$ FCS (BioWhittaker, Inc.). Hypoxic treatments were done in a hypoxic workstation (Ruskinn Technology, Ltd.) in a mixture of gases containing $2 \% \mathrm{O}_{2}, 5 \% \mathrm{CO}_{2}, 10 \% \mathrm{H}_{2}$, and $83 \% \mathrm{~N}_{2}$.

ELISA. Microplate wells were coated overnight at $37^{\circ} \mathrm{C}$ with the RIPA cell extracts diluted in PBS or $10 \mathrm{ng} /$ well of GST fusion proteins. After blocking with $10 \%$ FCS in PBS, the coated wells were incubated with $10 \mu \mathrm{g} / \mathrm{ml}$ of mG250 or cG250, depending on the experimental setting. Peroxidase-labelled 
pig anti-mouse IgG or goat anti-human IgG (Sigma) were used as detectors.

ELISA for evaluation of $m G 250$ cross-reactivity to CA I, II and XII. Microplate wells were coated overnight with the following antigens diluted in PBS: purified CA I (200 ng/well), purified CA II (100 ng/well) and recombinant CA XII (100 ng/well), all kindly provided by Professor Seppo Parkkila (University of Tampere, Finland). Then, the coated wells were incubated with $\mathrm{mG} 250$ and with polyclonal sera against CA I, CA II and CA XII (all 1:1,000), respectively, as positive controls. Peroxidase-labelled pig anti-mouse IgG and pig anti-rabbit IgG diluted 1:5,000 (Sigma) were used as detectors.

Competitive antibody-binding ELISA. An extract from MDCK-CA9 cells was adsorbed on microplate wells at a concentration corresponding to $50 \%$ of maximal binding of labelled MAbs. Coated plates were washed and saturated with $10 \%$ FCS in PBS. Serial 2-fold dilutions of purified mouse MAbs in $25 \mu \mathrm{l}$ and a constant amount of biotinylated MAb in $25 \mu \mathrm{l}$ were added and incubated overnight at $4^{\circ} \mathrm{C}$. The plates were washed and peroxidase-labelled streptavidin (Pierce Biotechnology, Inc.) was used as a detector.

Capture-detection ELISA. Microplate wells were coated with $50 \mu \mathrm{l} /$ well of individual purified mouse MAbs diluted in PBS $(200 \mu \mathrm{g} / \mathrm{ml})$. After blocking, washing and incubation with the extract of MDCK-CA9 cells (1:50 in PBS), the set of biotinylated antibodies $(5 \mu \mathrm{g} / \mathrm{ml})$ was added. Binding of the detector MAbs was determined using peroxidase-conjugated streptavidin. Results were expressed as absorbance differences between the wells, in which CA IX antigen was present or absent.

Competitive binding of $m G 250$ and inhibitor. CGL3 cells (with natural, hypoxia-induced expression of CA IX) and MDCK-CA9 cells (with constitutive, ectopic expression of CA IX) were plated in triplicates to wells of microplates and allowed to form a confluent monolayer overnight. Then the cells were transferred to hypoxia $\left(2 \% \mathrm{O}_{2}\right)$ for $24 \mathrm{~h}$. The inhibitor homosulfanilamide was diluted in culture media and added to the cells in increasing amounts together with a constant amount of G250 MAb $(200 \mu \mathrm{g} / \mathrm{ml}$ based on the saturation experiment) for the last $6 \mathrm{~h}$-period of the hypoxic incubation. Medium without the inhibitor was added to the control sample. The cells were fixed with methanol $(5 \mathrm{~min}$ at $-20^{\circ} \mathrm{C}$ ) and the amount of $\mathrm{mG} 250 \mathrm{MAb}$ bound to cells was determined by peroxidase-labelled anti-mouse IgG.

Immunoprecipitation. Tested mG250 MAb, M75 (as an anti-PG domain control) and VII/10 (as an anti-CA domain control) were bound to a $25 \mu 150 \%$ suspension of Protein A Sepharose (Pharmacia) for $2 \mathrm{~h}$ at RT. Biotinylated extracts of MDCK-CA9, MDCK- $\triangle \mathrm{CA}, \mathrm{MDCK}-\triangle \mathrm{PG}, \mathrm{MDCK}-\mathrm{hAS}$, and CGL3 cells (200 $\mu \mathrm{l}$ each), or media from biotinylated CGL3 cells treated with PMA (activator of shedding) and MDCK-hAS cells $(1,500 \mu \mathrm{l})$ were pre-cleared with $20 \mu \mathrm{l}$ of a $50 \%$ suspension of Protein A Sepharose and then added to bound MAb. Immunocomplexes collected on Protein A
Sepharose were washed, boiled $5 \mathrm{~min}$ in Laemmli loading buffer and separated by SDS-PAGE on a $10 \%$ gel. Afterwards, the proteins were transferred onto a PVDF membrane and detected with peroxidase-conjugated streptavidin $(1: 1,000$; Pierce Biotechnology, Inc.) followed by ECL.

Protein-A binding analysis by flow cytometry. HT-29 cells were incubated with $100 \mu \mathrm{g} / \mathrm{ml} \mathrm{mG} 250$ antibody for $1 \mathrm{~h}$ at $37^{\circ} \mathrm{C}$ to recruit the maximum of MAb to CA IX at the cell surface. Subsequently, the cells were washed to remove unbound antibody and left in fresh medium at $37^{\circ} \mathrm{C}$ for the internalization of bound $\mathrm{mG} 250$ for different periods of time $(0,3,24,48$ and $72 \mathrm{~h})$. At the end of the internalization period, Fc portions of the antibody remaining/recycled on/to the cell surface were detected by Protein A conjugated with Alexa Fluor 488 (Invitrogen Life Technologies) diluted 1:100 for $2 \mathrm{~h}$ at $4^{\circ} \mathrm{C}$ to prevent continued internalization. Data acquisition and analysis were performed on a Guava flow cytometer using CytoSoft software.

Immunofluorescence internalization assay. Cells plated on sterile glass coverslips $24 \mathrm{~h}$ before the experiment were incubated with $10 \mu \mathrm{g} / \mathrm{ml} \mathrm{cG} 250$ antibody for $30 \mathrm{~min}$ at $4^{\circ} \mathrm{C}$ to recruit the MAb to CA IX at the cell surface. Subsequently, the cells were washed to remove any unbound antibody and transferred to $37^{\circ} \mathrm{C}$ for various time intervals to allow for the internalization of CA IX-bound G250. Alternatively, the MAb was left in the medium throughout the experiment. At the end of the internalization period, the cells were washed and fixed in ice-cold methanol at $-20^{\circ} \mathrm{C}$ for $5 \mathrm{~min}$ and sequentially treated for $1 \mathrm{~h}$ at $37^{\circ} \mathrm{C}$ with anti-human Alexa-conjugated antibody (Invitrogen Life Technologies) diluted 1:1,000 to detect internalized cG250. Finally, the cells were thoroughly washed, mounted onto slides in the Fluorescent Mounting Medium (Calbiochem), analysed with a Leica DM4500 B microscope and photographed with a Leica DFC480 camera or by a confocal laser-scanning microscope Zeiss LSM 510 Meta.

Animal experiments. The therapeutic effect of MAb G250 was investigated in nude mice with tumour xenografts generated from HT-29 colorectal carcinoma cells. Animal handling was approved by the Slovak Veterinary Administration in accordance with EU regulations. For the immunotherapy experiment, $3 \times 10^{5}$ HT-29 cells in $200 \mu$ of PBS were grafted subcutaneously to the mouse back. Immediately (within $1 \mathrm{~h}$ ) after tumour cell grafting, one group of mice received intravenous injections of $100 \mu \mathrm{g} /$ dose of $\mathrm{mG} 250$ in PBS and the other two groups received PBS without the MAb. All subsequent injections were given into the tail vein twice a week throughout the tumour growth (39 days). To get closer to the situation in humans, where treatment is initiated only after detection of the growing tumour, a delayed mG250 treatment was started in the second group from day 10 after xenografting when the first tumours became palpable. Then the regimen of the treatment was the same as for the first group of animals. The third, control group received only PBS injections at the same time points as the antibody-treated animals. Tumour diameters were regularly measured and recorded. On the day of sacrifice, tumours were dissected, weighed and processed for immunohistochemistry. Serum 

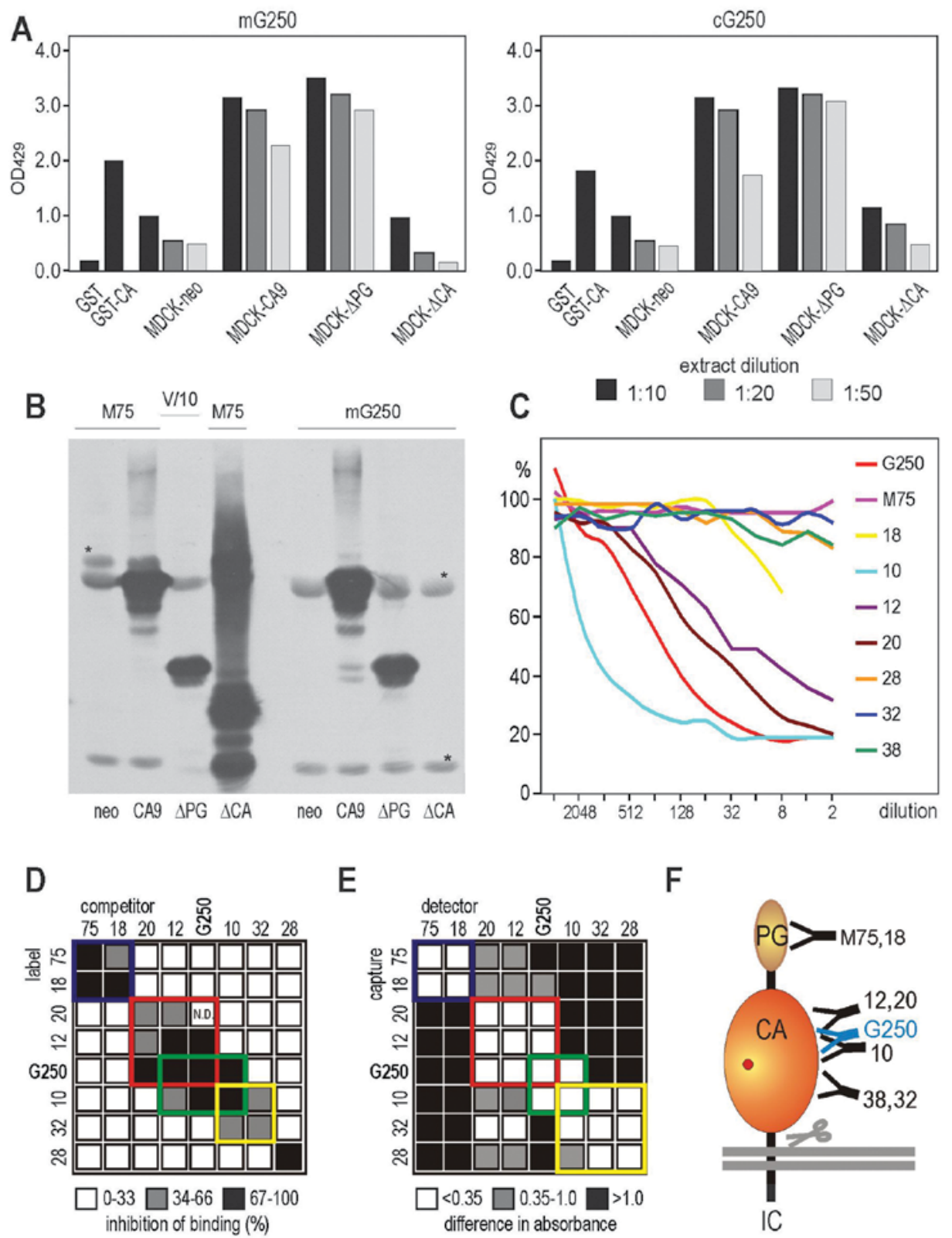

E

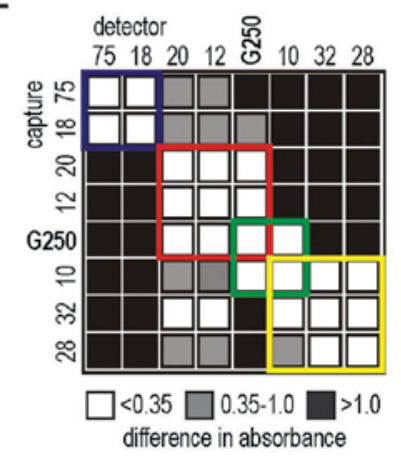

F

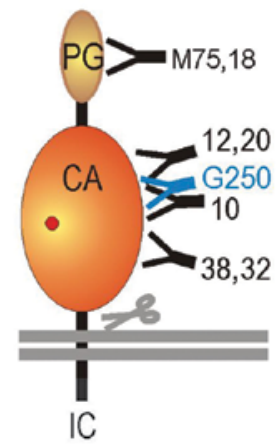

Figure 1. G250 monoclonal antibody (MAb) binding properties - domain specificity. (A) The target domain of the parental murine mG250 and chimeric cG250 MAbs was determined by ELISA using the following antigens: a recombinant fusion protein composed of the catalytic domain of carbonic anhydrase protein (CA IX) (aa 191-397) fused to GST (GST-CA) and GST alone, extract of transfected MDCK cells expressing the full-length CA IX (MDCK-CA9), or the deletion variant lacking the PG domain (MDCK- $\Delta \mathrm{PG}$ ), or the deletion variant lacking the carbonic anhydrase (CA) domain (MDCK- $\triangle \mathrm{CA}$ ). (B) The CA domain specificity of G250 MAb was confirmed by immunoprecipitation of the full-length human carbonic anhydrase gene (CA9) and its deletion variants from biotinylated cell extracts with G250 MAb as well as with M75 and V/10 MAbs as controls as described in Materials and methods. (C) The competitive ELISA was performed with the biotin-labeled G250 competing for binding to CA IX antigen from MDCK-CA9 cell extract against increasing concentrations of the simultaneously added non-labeled CA IX-specific antibodies characterized previously by Zatovicova et al, 2003, including the antibodies M75 and 18 specific for the PG domain and the antibodies 10,12, 20,28,32 and 38 specific for the CA domain. The extent of competition was expressed in \% relative to the G250 binding in the absence of competitor. (D and E) The relative position of the antigenic site of G250 among the other CA IX-specific monoclonal antibodies was schematically illustrated on Chequer-board maps of antigenic sites delineated on the basis of (D) the competitive binding ELISA and (E) capture-detection ELISA described in Materials and methods. Results are expressed (D) as percentage of absorbance measured in the absence of competitor antibody or (E) as absorbance resulting from the cooperative binding of capture-detector antibodies, which indicates spatial separation between the epitopes of the paired antibodies. (F) Schematic illustration of relative positions of the binding sites for the monoclonal antibodies deduced on the basis of their domain specificity and mutual binding relationships. Scissors indicate the region of the ectodomain (ECD) cleavage.

samples were also collected from all groups to detect the CA IX ECD.

ELISA detection of shed human CA IX ECD in mouse serum samples. The capture antibody VII/38 $(10 \mathrm{mg} / \mathrm{ml}$, $100 \mathrm{ml} /$ well) was immobilized on the surface of microplate wells overnight at $4^{\circ} \mathrm{C}$. After blocking and washing, mouse serum samples were diluted 1:2 in PBS and added to the coated wells $(100 \mathrm{ml} /$ well $)$ for overnight binding at $4^{\circ} \mathrm{C}$. The attached antigen was then allowed to react with biotinylated M75 MAb diluted 1:5,000 $(200 \mathrm{ng} / \mathrm{ml})$ in PBS. The amount of bound detector antibody was determined after $1 \mathrm{~h}$ incubation with 
the peroxidase-conjugated streptavidin (Pierce Biotechnology, Inc.) using the peroxidase substrate ortho-phenylene diamine (Sigma).

\section{Results}

Binding of cG250 MAb to CA IX deletion variants. Earlier studies showed that G250 MAb interacts with the native CA IX protein, but its domain specificity has remained unknown (22). Thus, we first analysed the binding of G250 $\mathrm{MAb}$ to CA IX variants with deletions of various parts of the molecule. ELISA with these CA IX-related antigens revealed that G250 MAb (both mouse and chimeric versions) bound only to those variants that contained an intact CA domain, including GST-CA and extracts from MDCK-CA9 and MDCK- $\triangle$ PG cells (Fig. 1A). Accordingly, mG250 MAb was capable of immunoprecipitating only the full-length CA IX protein and its $\triangle \mathrm{PG}$ variant (Fig. 1B), but not the $\triangle \mathrm{CA}$ variant lacking the catalytic domain, as was shown previously for other CA domain-specific MAbs (24). A competitive antibody-binding ELISA was then performed to analyse mutual relationships among these MAbs and derive the position of $\mathrm{mG} 250$ on the epitope map of the CA IX antigen. Only the CA domain-specific antibodies VII/20, V/12 and V/10 were able to compete for the binding to CA IX with labelled mG250 to an extent similar to the homologous competition by non-labelled mG250 (Fig. 1C). A capture-detection assay corroborated the relationships between the antibodies with minor differences attributable to the different arrangement of the assay (Fig. 1D).

Binding of cG250 MAb to naturally occurring CA IX variants, orthologs and other CA isoforms. CA IX protein exists in three naturally occurring forms, namely the full-length protein, the ECD shed to extracellular space and the alternatively spliced (AS) variant that is partially intracellular and partially secreted $(20,21,46)$. The CA IX ECD can be detected in body fluids of cancer patients and appears to have a prognostic/monitoring value (47-53). On the other hand, the truncated AS variant is produced at a low level independently of hypoxia and tumour phenotype and for immunotherapy its interaction with CA IX antibodies is not desirable due to possible interference with the binding of the clinically relevant CA IX molecules (46). Indeed, ELISA and immunoprecipitation of CA IX variants from extracts of transfected cells or natural CA IX expressors demonstrated that mG250 MAb recognizes only the full-length CA IX protein and its extracellular domain shed to medium, but not the AS variant lacking the C-terminal part of the catalytic domain (Fig. 2A and B).

Since $\mathrm{G} 250$ binds to the CA domain, we analyzed whether it can also recognize related CA isoforms (particularly those that could be co-expressed with CA IX in tumour cells). We used ELISA to test the binding of G250 MAb (both mouse and chimeric versions) to purified CA I, CA II, and CA XII antigens, and found that G250 did not bind any of the CA isoforms tested (Fig. 2C). Moreover, neither mouse nor rat CA IX orthologs interacted with G250 suggesting that it specifically reacts with the human CA IX antigen (Fig. 2D). Therefore, it can be investigated in animal models with human tumour xenografts, but not with natural, induced, syngeneic tumours or mouse/rat xenografts.
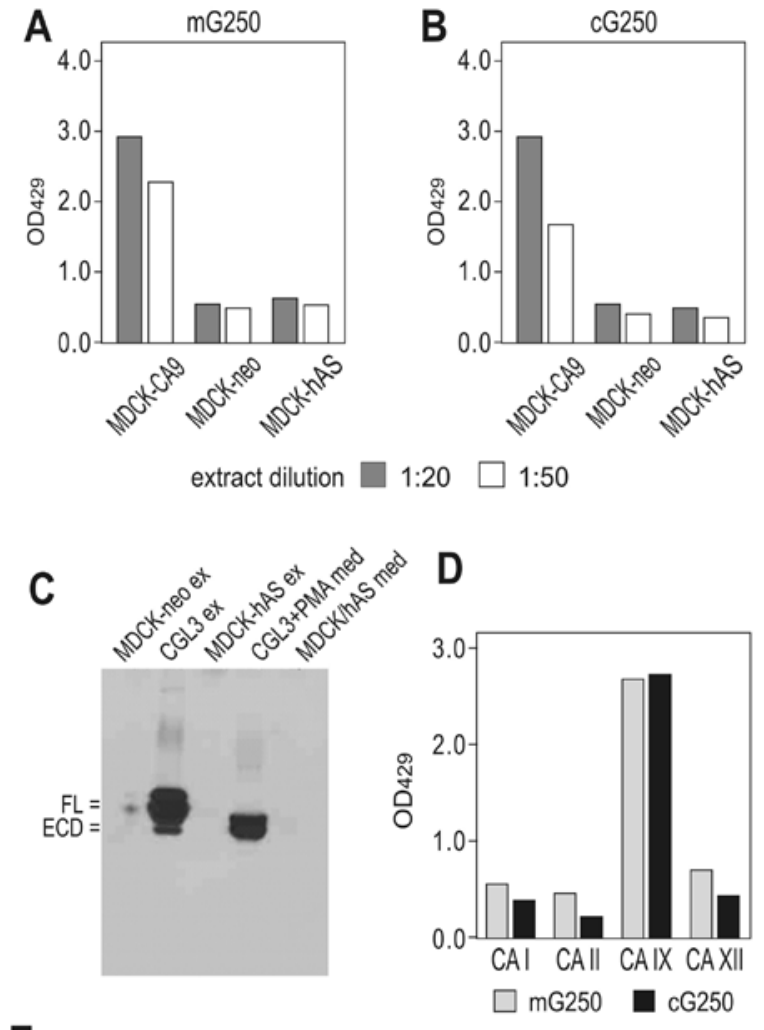

E

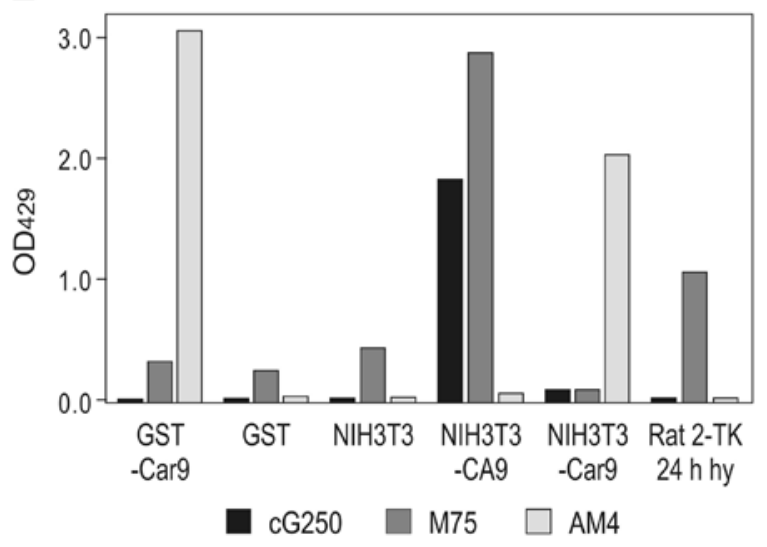

Figure 2. G250 monoclonal antibody (MAb) binding properties - antigen/isoform specificity. (A and B) Binding of the G250 MAb (its mouse and chimeric versions) to the full-length carbonic anhydrase protein (CA IX) protein versus the alternatively spliced variant was determined by ELISA using the extracts of MDCK cells transfected with the full-length human carbonic anhydrase gene (CA9) cDNA (MDCK-CA9), its splicing variant lacking the exons 8 and 9 (MDCK-hAS), and mock-transfected control (MDCK-neo). (C) Ability of mG250 MAb to recognize the full-length CA IX (FL) and its ectodomain (ECD), but not the alternatively spliced variant (hAS) was demonstrated by immunoprecipitation using the extracts and media from CGL3 cells naturally expressing CA IX and from the transfected MDCK cells (MDCK-hAS), followed by the western blotting with the M75 MAb. (D) CA IX isoform specificity of the mG250 and cG250 MAbs was proven by ELISA using purified antigens of the CA I, II, IX and XII isoenzymes as described in Materials and methods. (E) cG250 specificity for the human CA IX was shown by ELISA using the mouse CA IX fused to GST (GST-Car9), extracts of NIH3T3 cells transfected either with the human CA9 cDNA or with the mouse rodent carbonic anhydrase gene (Car9) cDNA, and hypoxic Rat 2-TK-cells naturally expressing rat CA IX. M75 MAb, which recognizes both human and rat CA IX, and MAb AM4, which recognizes mouse CA IX, were used for control.

Binding of cG250 MAb to CA IX in presence of CA inhibitor. The CA domain of CA IX is a globular structure containing 

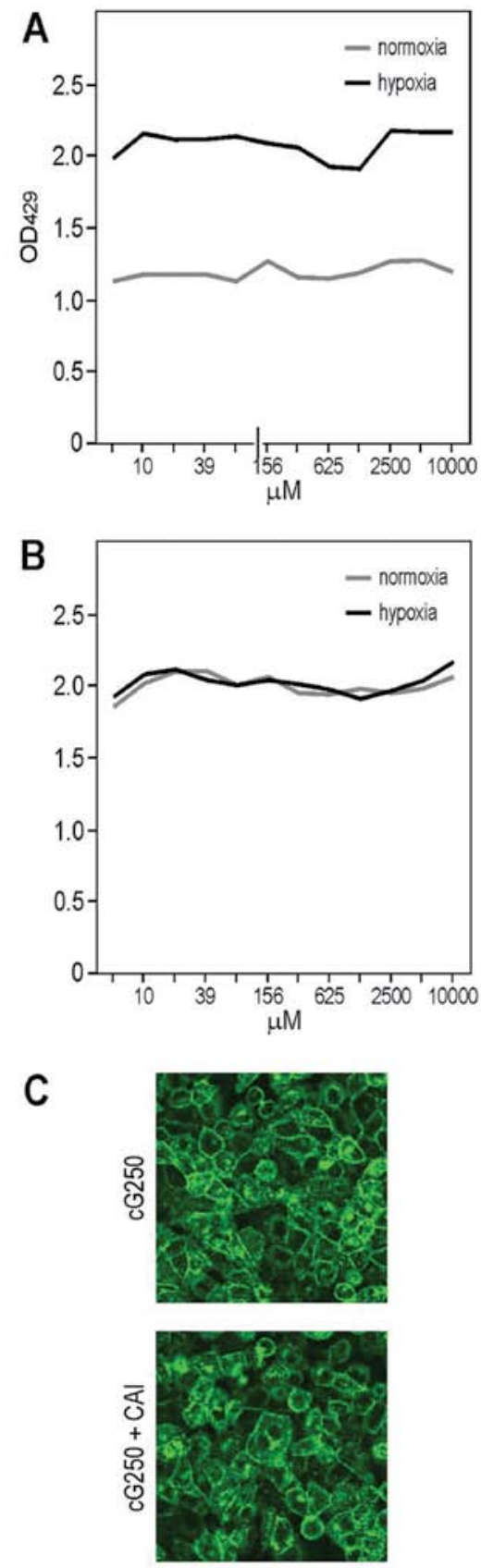

Figure 3. cG250 monoclonal antibody (MAb) binding in presence of carbonic anhydrase (CA) inhibitor homosulfanilamide. (A) CGL3 cells and (B) MDCK-CA9 cells were plated in triplicate wells to microplate and allowed to form confluent monolayers overnight. Then the plates were transferred to hypoxia $\left(2 \% \mathrm{O}_{2}\right)$ for $24 \mathrm{~h}$. Control plates were maintained in normoxia. CA inhibitor was added to cells in increasing concentrations together with a constant amount of cG250 MAb (200 $\mu \mathrm{g} / \mathrm{ml}$ based on the saturation experiment) for the last $6 \mathrm{~h}$ of the incubation period. Then, cells were fixed with methanol and cG250 MAb binding was determined by peroxidase-labeled anti-human $\mathrm{IgG}$. The difference in absorbance values between hypoxia and normoxia corresponds to hypoxic induction of carbonic anhydrase protein (CA IX) in CGL3 cells. MDCK-CA9 cells have similar absorbance values for normoxia and hypoxia because these transfected cells express CA IX constitutively. (C) cG250 binding to CGL3 cells in absence and presence of the inhibitor was also visualized by immunofluorescence. The cells were grown as described in (A) and (B), transferred to hypoxia and treated with inhibitor at $10 \mathrm{mM}$ concentration together with cG250 MAb $(200 \mu \mathrm{g} / \mathrm{ml})$.

the enzyme active site that is located in a large conical cavity with the catalytic zinc at the bottom (54). This active site can accommodate different types of carbonic anhydrase inhibitors (CAIs). Since CA IX activity plays an important role in tumour biology, these inhibitors have been investigated as clinically promising tools for detection and therapeutic targeting of hypoxia-activated CA IX $(11,18,55)$. We previously showed that the FITC-conjugated homosulfanilamide inhibitor (FITC-CAI) binds to CA IX expressed in hypoxic cells (7). Here we examined whether interaction of cG250 MAb to the catalytic domain of CA IX is affected by FITC-CAI binding to the active site. To this end we used a competitive ELISA on monolayers of hypoxic cells, namely CGL 3 cells with natural CA IX expression and MDCK-CA9 cells with ectopic CA IX expression. FITC-CAI was added in increasing amounts together with a constant amount of cG250 MAb $(200 \mu \mathrm{g} / \mathrm{ml}$ based on the saturation experiment, data not shown). CAI did not block the internalization of cG250 either (Fig. 3C). Moreover, in both cell lines, FITC-CAI did not reduce cG250 MAb binding (Fig. 3A and B), indicating that cG250 does not bind in or close to the active site, but rather interacts with the backbone of the catalytic domain. This suggests that CA IX-expressing hypoxic tumours can be potentially subjected to a combination treatment with cG250 and CAI.

Internalization of cG250: co-localization with CA IX, the effect of cell density and hypoxia. Binding of cG250 MAb to CA IX was shown to trigger receptor-mediated internalization, a process that has particular impact on the outcome of immunotherapy targeted to cancer-related antigens (56). Since we wanted to learn more about the temporal and mechanistic aspects of cG250 internalization, we followed the localization and fate of the internalized antibody for different time periods and under different conditions.

To analyze whether cG250 co-localizes with CA IX during the internalization path, the MAb was first recruited to the cell surface CA IX at $4^{\circ} \mathrm{C}$, then unbound antibody was washed away, internalization was initiated at $37^{\circ} \mathrm{C}$ and allowed to proceed for 3, 6, 24 and $48 \mathrm{~h}$. In all internalization periods, staining signals of cG250 antibody and CA IX antigen overlapped (Fig. 4A) suggesting that cG250 antibody remains associated with the antigen. Interestingly, intracellular staining of both cG250 and CA IX prevailed up till $24 \mathrm{~h}$ of internalization, whereas samples incubated for $48 \mathrm{~h}$ showed the membrane staining, apparently due to recycling of the cG250-CA IX complex back to the cell surface. Moreover, the analysis of cG250 internalization under hypoxia $\left(2 \% \mathrm{O}_{2}\right)$ and in acidic extracellular $\mathrm{pH}$ revealed that cG250 enters the intracellular space independently of these physiological conditions and confirms that it also remains associated with CA IX inside the cell (Fig. 4B). Interestingly, cG250 antibody remained associated with the cells at least for 3 days, even when the cells were split and re-plated (data not shown).

The distribution of immunotherapeutic antibodies in solid tumours reflects different physiological barriers including high cell density (57). We therefore examined internalization of cG250 in a highly packed cell monolayer under normoxia and hypoxia, respectively, using MDCK-CA9 cells with the constitutive expression of CA IX and CGL3 cells with high endogenous expression of CA IX. We found that cG250 MAb was unable to internalize into dense cells under normoxia, whereas hypoxia facilitated internalization presumably due to release of tight cell-cell contacts (Fig. 4C). This suggests that 

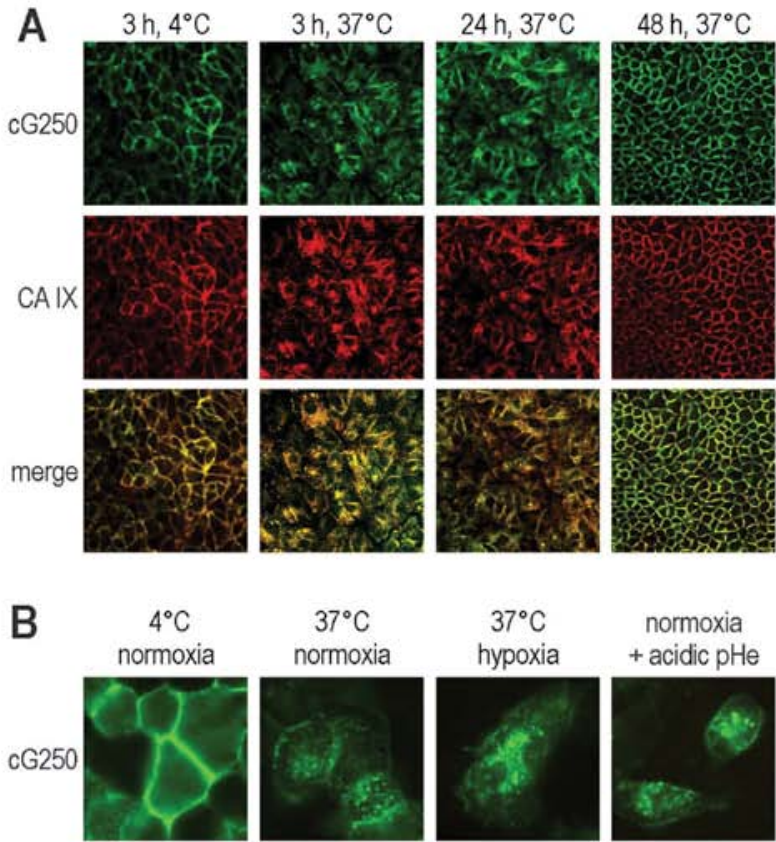

normoxia
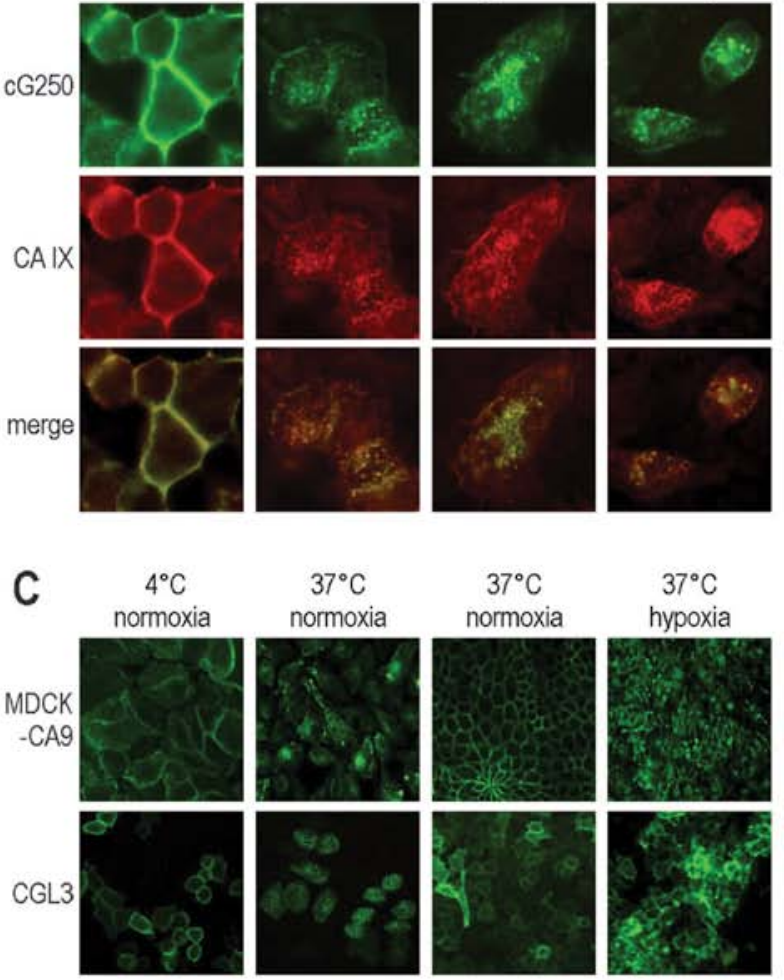

Figure 4. G250 monoclonal antibody (MAb) internalization: co-localization with carbonic anhydrase protein (CA IX) and effects of hypoxia, $\mathrm{pH}$ and cell density. In all experiments, cells were incubated with cG250 for $30 \mathrm{~min}$ at $4^{\circ} \mathrm{C}$ to recruit the MAb to CA IX at the cell surface, then washed to remove any unbound antibody and transferred to $37^{\circ} \mathrm{C}$ for various time periods to allow for the internalization of CA IX-bound G250. At the end of the internalization period, the cells were washed, fixed and treated with labeled secondary antibodies (green, anti-human to detect cG250; red, anti-mouse to detect CA IX antigen), then washed and analyzed by confocal microscopy. (A) cG250-CA IX co-localization was evaluated in normoxic MDCK-CA9 cells subjected to different cG250 internalization periods. (B) The effect of hypoxia and acidic $\mathrm{pH}$ was analyzed in MDCK-CA9 cells during a $3 \mathrm{~h}$ internalization period. The data show co-localization of cG250 with CA IX during the entire internalization experiment and demonstrate that hypoxia positively affects MAb internalization to densely cultivated cells. C) The effect of hypoxia on internalization in dense cells was evaluated using both MDCK-CA9 and CGL3 monolayers in comparison to internalization in sparsely and densely growing normoxic cells.

CA IX present on the surface of hypoxic and/or HIF-activated cancer cells can mediate antibody-induced internalization despite high local cell density.

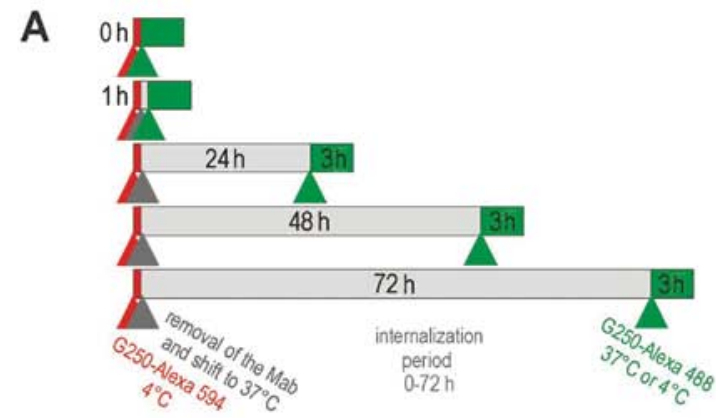

B
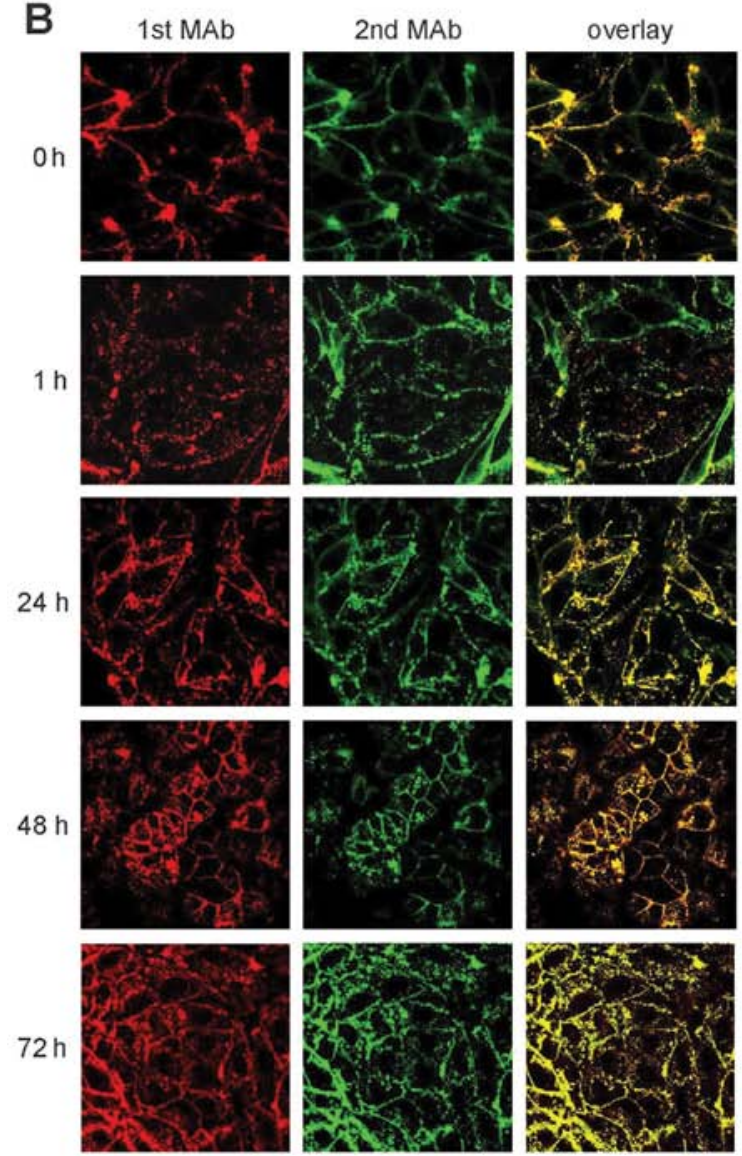

Figure 5. Internalization of two consecutively added cG250 monoclonal antibody (MAb) doses. (A) Experimental scheme showing time intervals between the 1st and 2nd antibody doses directly labeled with Alexa dyes (red, 594 and green, 488). The 1st dose of the cG250-Alexa 594 antibody $(10 \mu \mathrm{g} / \mathrm{ml})$ was recruited to carbonic anhydrase protein (CA IX) antigen for $30 \mathrm{~min}$ at $4^{\circ} \mathrm{C}$. Then, unbound antibody was washed and the cells were transferred to $37^{\circ} \mathrm{C}$ for various time intervals to allow for the internalization of CA IX-bound cG250. At the end of each interval, the 2 nd cG250-Alexa 488 antibody $(10 \mu \mathrm{g} / \mathrm{ml})$ was added and allowed to internalize for $3 \mathrm{~h}$. Then the cells were washed, fixed and analyzed by confocal microscopy. (B) Immunofluorescence analysis of the internalized antibodies showing that the second antibody internalized equally well independently of the time passed $(0,1,24,48$ and $72 \mathrm{~h})$ from the internalization of the 1st antibody.

Consecutive internalization cycles of cG250 MAb. We then investigated whether cG250 MAb is able to undergo consecutive internalization cycles via newly produced and/or unoccupied CA IX antigen present on the cell surface. The experimental scheme utilizing consequent green- and red-labelled G250 MAbs was set as shown in Fig. 5A. Confocal microscopic analysis revealed that both antibodies bound to CA IX and internalized irrespective of the time interval 

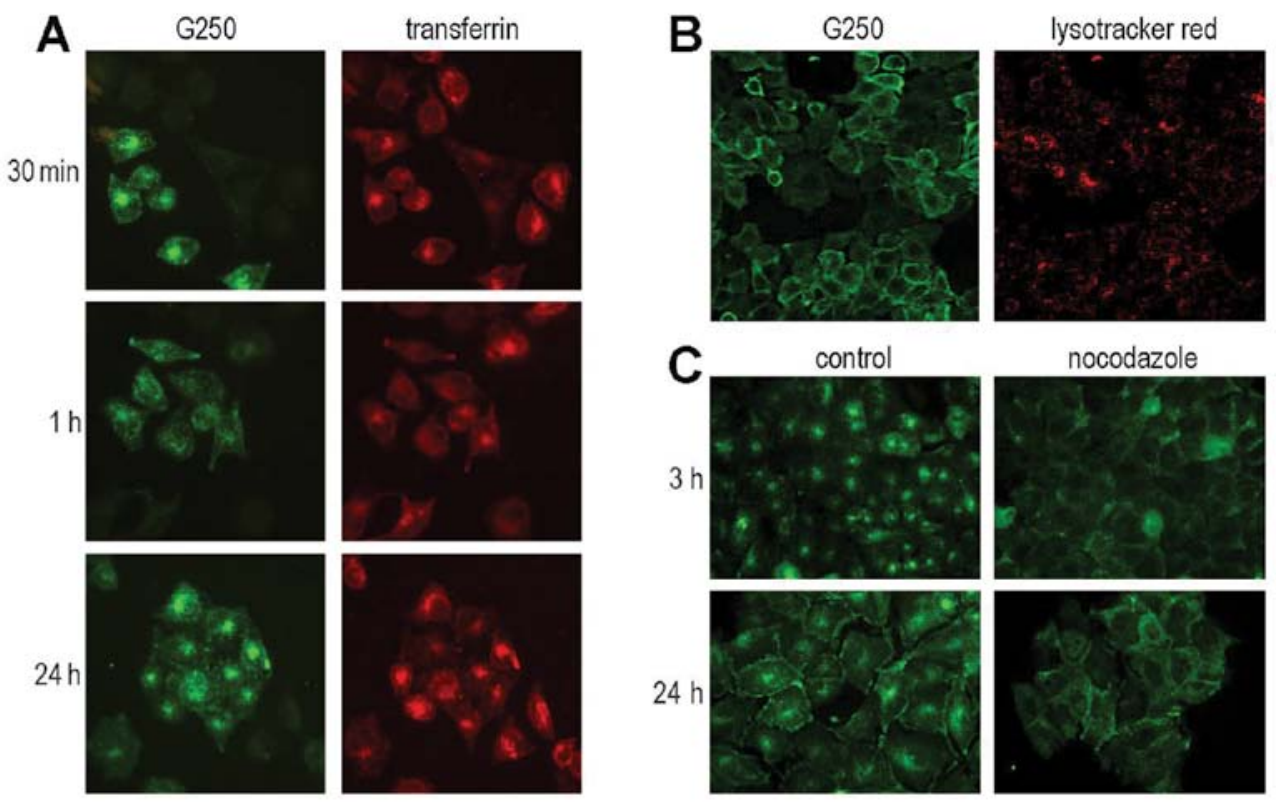

Figure 6. Internalization path of G250. (A) CGL3 cells were incubated at $37^{\circ} \mathrm{C}$ in medium containing G250 monoclonal antibody (MAb) and Alexa 568-labeled transferrin (TR). Membrane-bound TR and mG250 were acid-stripped either immediately before fixation (at 30 min and $1 \mathrm{~h}$ intervals) or after $3 \mathrm{~h}$ (for $24 \mathrm{~h}$ interval) and the rest of the incubation was done with TR/G250-free medium. Then the cells were fixed, treated with Alexa 488 anti-mouse IgG to detect mG250, washed, and analyzed by confocal microscopy. (B) MDCK-CA9 cells were incubated with the FITC-conjugated mG250 MAb for $30 \mathrm{~min}$ at $4{ }^{\circ} \mathrm{C}$, then were transferred to $37^{\circ} \mathrm{C}$ for $3 \mathrm{~h}$ and $75 \mathrm{nM}$ LysoTracker Red was added to the medium with mG250-FITC MAb 30 min before the end of the experiment. Finally, the cells were washed and immediately subjected to confocal analysis. (C) MDCK-CA9 cells were treated first with $5 \mu \mathrm{M}$ nocodazole for $1 \mathrm{~h}$, then $3 \mu \mathrm{g} / \mathrm{ml}$ of the $\mathrm{mG} 250 \mathrm{MAb}$ was allowed to bind to cells for $30 \mathrm{~min}$ at $4^{\circ} \mathrm{C}$, the cells were transferred to $37^{\circ} \mathrm{C}$ for $3 \mathrm{~h}$ to permit internalization. Unbound antibody was washed and cell surface-bound antibody was acid-stripped, the fresh medium (with or without nocodazole) was added to one pair of dishes to continue the intracellular processing of the mG250 MAb for additional $69 \mathrm{~h}$. At the end of the internalization period, cells were washed, fixed, incubated with Alexa 488 anti-mouse IgG, washed again and analyzed by confocal microscopy.

between their addition to cells (see Fig. 5). Interestingly, there were no big differences in the subcellular localization of the 1st versus 2 nd antibody, and both antibodies showed considerable co-localization. A slight difference could be seen in the 1-h sample, where the red signal seemed to dominate in the intracellular space, while the green signal prevailed on the cell surface. In the samples with 24 and $72 \mathrm{~h}$ internalization period, both red and green signals overlapped, while a slight red intracellular staining was visible again in the sample with the $48 \mathrm{~h}$ internalization period. These very subtle differences might reflect partly asynchronous movement (e.g., time-shift in internalization-recycling) of the red and green MAbs in the cells.

cG250 internalization pathway, recycling and integrity of Fc fragment. To gain insight into the fate of internalized cG250 we used several inhibitors and markers of the internalization pathways. We could see that the pattern of cG250 internalization is very similar to transferrin (TR) a molecule known to enter cells in a clathrin-dependent manner (Fig. 6A). Consistent with this, nystatin, a cholesterol-aggregating inhibitor of clathrin-independent endocytosis, did not have any effect on cG250 internalization (data not shown). Moreover, no major differences in cG250 internalization patterns were observed following treatment with the lysosomotropic agent concanavalin A (data not shown). Indeed, cG250 MAb showed no or only a minor overlap with LysoTracker Red lysosomal marker in support of the idea that the major part of the antibody escapes lysosomal degradation and enters the recycling pathway (Fig. 6B). Finally, we performed internalization of cG250 in the presence of nocodazole, a microtubule-disrupting agent, which reduces the transit of internalized molecules to the perinuclear compartment and thereby inhibits their recycling. This led to loss of perinuclear localization of cG250, diminished recycling to the plasma membrane and to its diffuse distribution throughout the entire cytoplasm (Fig. 6C).

We further evaluated the internalized/recycled cG250 $\mathrm{MAb}$ with respect to the integrity of its Fc portion, which mediates ADCC response, i.e., directs cytotoxic activities of effector cells against the target cell. We first examined the capacity of cG250 to bind Protein A in immunofluorescence analysis, which showed that the antibody can bind Protein A at each point of the internalization cycle, i.e., initially on the cell surface, then inside the cells and finally on the cell surface again (Fig. 7A). Flow cytometric analysis of HT-29 cells that highly express CA IX revealed that the percentage of Protein A-positive cells (in which Protein A was bound to cG250 MAb attached to CA IX at the surface of living cells) decreased from initial 72 to $55 \%$ after $3 \mathrm{~h}$ internalization and to $18 \%$ after $24 \mathrm{~h}$ (Fig. 7B). This decline agrees with the strength of the intracellular signal observed in immunofluorescence and suggests a reduction of the antibody on the cell surface as a consequence of internalization. On the other hand, gradual elevation of the Protein A-binding cells to 31\% after $48 \mathrm{~h}$ and $45 \%$ after $72 \mathrm{~h}$ suggests that the antibody recycled back to the plasma membrane, although it did not reach the initial level (Fig. 7B). This reduction could be due either to partial degradation of the internalized antibody or, more 

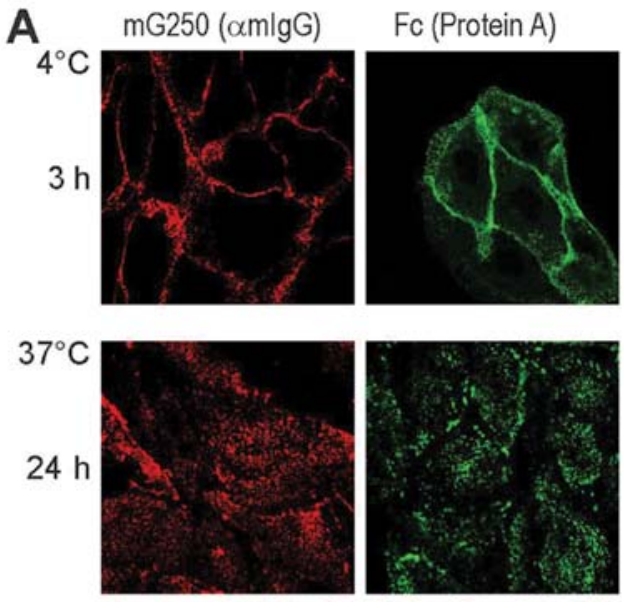

48
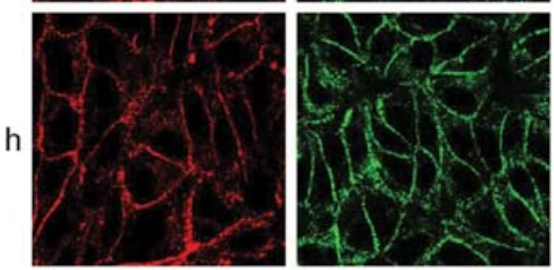

72
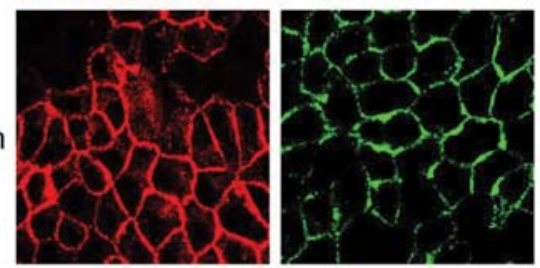

B

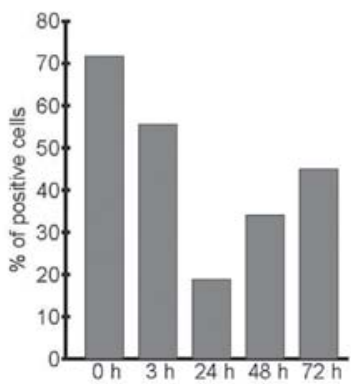

Figure 7. Integrity of internalized and recycled G250 monoclonal antibody (MAb). (A) MDCK-CA9 cells were incubated with mG250 MAb for $30 \mathrm{~min}$ at $4^{\circ} \mathrm{C}$ to recruit it to carbonic anhydrase protein (CA IX) at the cell surface, and then transferred to $37^{\circ} \mathrm{C}$ for $3 \mathrm{~h}$ to trigger internalization Unbound antibody was removed by washing. At the end of the subsequent internalization period $(3,24,48$ and $72 \mathrm{~h})$, the cells were washed, fixed, incubated with either Alexa 594-conjugated anti-mouse antibody to detect mG250 or with Alexa Fluor 488-conjugated Protein A to detect the Fc portion of the mG250 MAb, and were afterwards subjected to confocal analysis (B) Graph shows data from the flow cytometry analysis expressed as percentage of HT-29 cells binding protein A to the Fc portion of G250 following internalization for various time intervals.

conceivably, to cell division during the long internalization periods that resulted in the relative dilution of the staining signal. Undoubtedly, these results confirm that the recycled antibody possesses an intact Fc portion.

In vivo anti-tumour effects of $G 250$ in a non-RCC xenograft model. In order to learn whether G250-based immunotherapy can be useful in tumours other than RCC, we investigated its anticancer effect against HT-29 colorectal carcinoma xenografts implanted in nude mice. This model was chosen because HT-29 cells display high expression of CA IX even under normoxia. Although hypoxic induction of CA IX in monolayer culture of HT-29 cells is relatively low, its distribution in xenografts displays a typical hypoxic pattern with high perinecrotic expression of CA IX and low or no expression around vessels as demonstrated earlier (36).

The xenografted animals were subjected to immediate as well as to delayed treatment with $\mathrm{mG} 250$ as described above in Materials and methods. Both groups showed a significant reduction of tumour volume and tumour weight when compared to control, placebo-treated animals suggesting that $\mathrm{mG} 250$ is capable of eliciting not only a protective, but also a real therapeutic anti-cancer effect in a setting similar to the treatment of cancer patients (Fig. 8A and B).

We also wanted to find out whether the presence of the HT-29 tumour is reflected in serum levels of the CA IX ECD. For this purpose, we adopted a capture-detection ELISA using a combination of the CA domain-specific VII/38 MAb and the PG domain-specific M75 MAb. The analysis revealed detectable serum levels of the CA IX ECD in tumour-bearing animals (Fig. 8C). Although levels of CA IX ECD did not fully correlate with the weights of tumours (conceivably due to differences in tumour tissue heterogeneity, extent of hypoxia and intratumoural levels of CA IX) these data principally support the monitoring potential of CA IX serum levels.

\section{Discussion}

In this study, we describe novel data that clarify the binding characteristics and biological properties of the therapeutic MAb cG250 (INN: Girentuximab) and provide the experimental evidence supporting its potential usefulness in immunotherapy of tumours other than RCC.

We show here that the G250 MAb possesses several attributes favourable to its clinical application in targeting of the CA IX antigen, which has a unique tumour-associated expression pattern and biological relevance for the tumour phenotype. These attributes include i) specific recognition of the human CA IX protein, but not the other CA isoforms; ii) binding to the catalytic domain without interfering with its small molecule active site inhibitors; and iii) no binding to the alternatively spliced variant of CA IX. Thus, our data prove the high CA IX antigen specificity and selectivity of the $\mathrm{G} 250 \mathrm{MAb}$, which is in line with the observations of excellent antibody tolerability and safety in RCC patients included in G250 immunotherapy-based clinical trials (23). The data also suggest that G250-mediated immunotherapy can be potentially combined with the therapy based on inhibition of CA IX activity. The same conclusion can be applied to the use of G250 in CA IX-related imaging of primary and metastatic tumour lesions.

Moreover, G250 can induce receptor-mediated internalization, as also described earlier (56). However, we found that the CA IX-mediated internalization induced by G250 can proceed in consecutive cycles and that in contrast to other endocytosed ligand-receptor or antibody-antigen complexes, G250-CA IX complex has an exceptionally long intracellular persistence of 48-72 h. Throughout this period, antibody-antigen interaction seems to remain undisturbed and the complex can then recycle back to the cell surface in its 

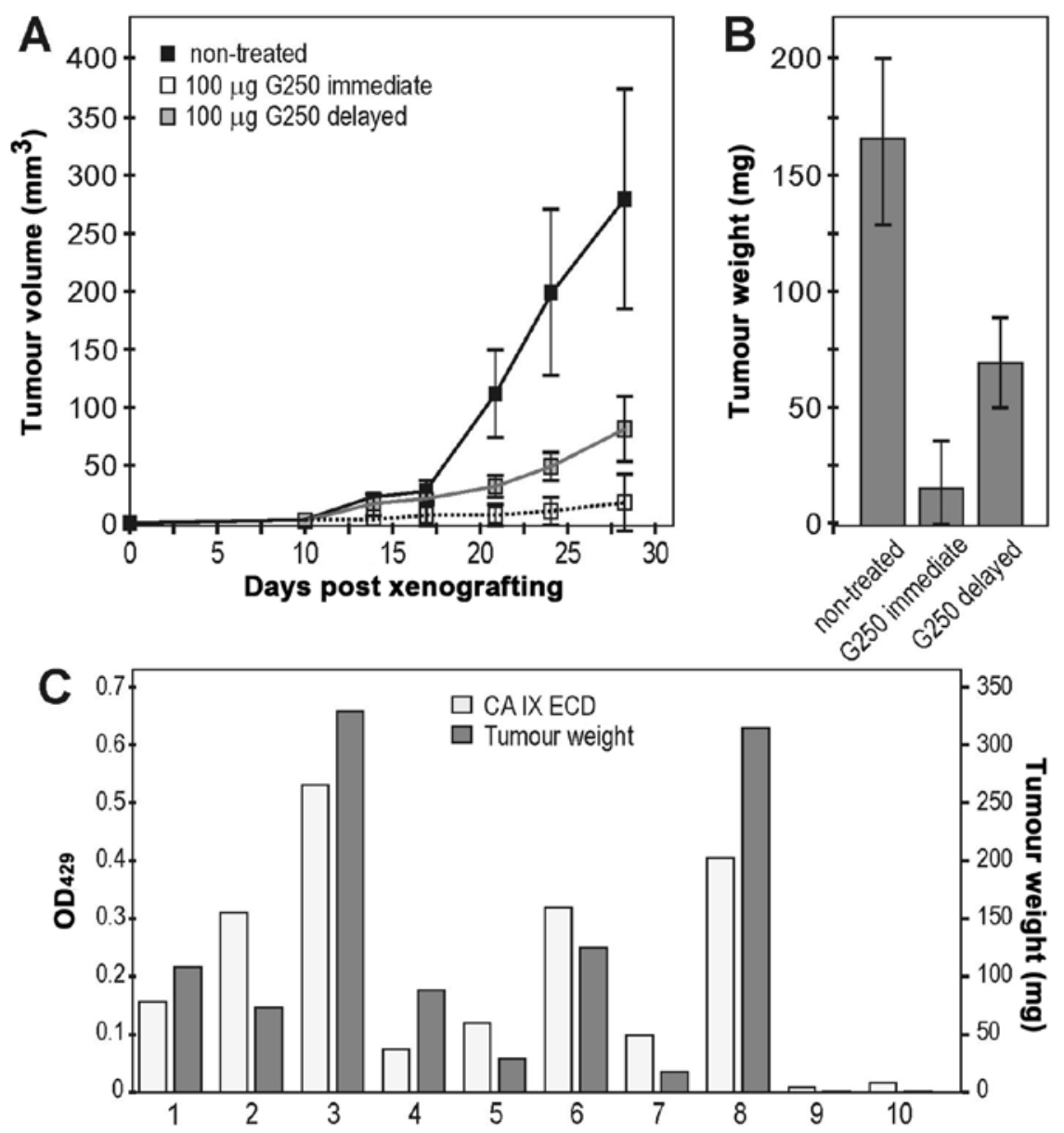

Figure 8. In vivo anticancer effects of mG250 monoclonal antibody (MAb) on tumour growth and serum levels of shed carbonic anhydrase protein (CA IX) ectodomain (ECD). (A) Graph illustrating volumes of tumours grown from subcutaneously xenografted HT-29 cells in mice subjected to either immediate or delayed onset of treatment with mG250 MAb in comparison to non-treated controls ( $\mathrm{n}=20$ per group) as calculated from caliper measurements. (B) Tumour weight confirming the anticancer effects of $\mathrm{mG} 250$ with immediate or delayed onset of therapy after engraftments of tumour cells. (C) Relationship between individual levels of CA IX ECD shed to sera of the xenografted mice and weights of the corresponding tumours.

principally intact form with the preserved $\mathrm{Fc}$ part of the G250 MAb. These findings are important for the understanding of the therapeutic efficacy of the antibody. Firstly, the consecutive internalization can contribute to better utilization of the therapeutic antibody, which does not immediately bind to the antigen and remains in its free form in the pericellular space, or which arrives later from the circulation. Secondly, long intracellular persistence can potentially modulate the intracellular signalling of CA IX, since it is known that regulatory receptors can either extend or cease their signalling from endosomes (58). At present we do not have enough data to support or exclude this assumption. Third, recycling and cell surface exposure of the G250 antibody with the intact $\mathrm{Fc}$ fragment can allow for prolonged ADCC response, which represents its principal anticancer mode of action $(59,60)$. Recycling of intact G250 can also explain its long-lasting effects in patients (61).

The Phase III clinical trial 'ARISER' conducted in patients with non-metastatic ccRCC showed significant benefit of prolonged disease-free survival of $\sim 22$ month in patients with high CA IX score in the resected primary tumours compared to patients in the placebo arm (44). Thus, the situation in G250-mediated immunotherapy of RCC seems promising in patients with tumours with high CA IX score. Frequent and strong expression of CA IX is observed in a high percentage of tumour cells in RCC tissues $(22,33)$. But, can we expect similar or any anticancer effect in patients with other tumour types? There, CA IX expression is heterogeneous (with respect to both loco-regional distribution and cellular expression levels) owing to its principal link with hypoxia (5). Importantly, more frequent and intense expression is seen in more hypoxic and aggressive tumours. According to the generally accepted view, hypoxic tumour areas are poorly accessible by antibodies and drugs, because of their greater diffusion distance from the functional blood vessels as well as to the increased cell density (57). However, CA IX expression is not limited to perinecrotic regions, but rather extends toward less distant areas with less severe hypoxia. The median distance between a blood vessel and the beginning of CA IX expression was $80 \mu \mathrm{m}$ (range, 40-140) in head and neck carcinoma and bladder carcinoma $(62,63)$ and $\sim 90 \mu \mathrm{m}$ in non-small-cell lung carcinoma (64). Thus, CA IX is found between the borders of HIF-1 $\alpha$ zone and a zone of EF5 chemical marker of hypoxia suggesting that CA IX induction requires lower oxygen levels than HIF-1 $\alpha$, but higher than EF5 (or pimonidazole). These intermediate, 
moderately hypoxic tissue areas are known to contain viable cells that are adaptable to hypoxic stress, resistant to conventional therapy, and represent the principal source of metastatic precursors (65). Indeed, it was demonstrated that the cells expressing CA IX belong to a broader perinecrotic area and are viable, clonogenic and resistant to killing by ionizing radiation (66). Therefore, it appears that the G250 antibody does not need to diffuse to the most remote distances from the irregular but leaky tumour blood vessels to reach its target. Moreover, hypoxia is known to facilitate metastasis through the promotion of epithelial-mesenchymal transition, which involves initial destabilization of cell-cell contacts via modulated expression of cell adhesion molecules and extracellular matrix-degrading proteases (67). This can also contribute to lower cell density and reduced matrix stiffness, and hence to better penetration of the antibody across the tumour tissue as well as to its improved endocytosis. Indeed, earlier studies demonstrated that other CA IX-specific antibodies, namely the PG domain-binding MAb M75 as well as the CA domain-binding MAb VII/20, exhibit excellent tumour uptake and therapeutic efficacy, respectively, in the mouse models with non-RCC tumour xenografts containing hypoxic regions $(17,36)$. Similarly, the present study showed a considerable anticancer effect of $\mathrm{G} 250 \mathrm{MAb}$ in the non-RCC setting.

Taking all these circumstances together it is imaginable that the targeting of the intermediate (less distant), CA IX-positive, moderately hypoxic tumour cell subpopulation by cG250-mediated immunotherapy could eliminate the most aggressive and dangerous components of tumour tissue and potentially prevent, reduce, or delay the onset of the metastatic process, which is the main cause of death from cancer. Although additional extensive experimentation is needed to support this proposal, the recent study offers the rationale and substantiates the direction of the research towards the application of cG250 in immunotherapy of non-RCC cancer.

To conclude, we showed that G250 MAb (Girentuximab) that is primarily evaluated as an immunotherapy for kidney cancer, recognizes the catalytic domain of the hypoxia-induced CA IX protein. We found that the antibody G250 internalizes via clathrin-coated vesicles and recycles to cell surface via perinuclear compartment. This leads to long intracellular persistence and consecutive internalization cycles. The recycled antibody maintains intact Fc portion potentially capable of continuous induction of ADCC response and high therapeutic efficacy. Finally, we showed that G250-mediated immunotherapy is effective against HT-29 colorectal carcinoma xenografts that display heterogeneous, hypoxia-related expression of CA IX. These results support potential therapeutic usefulness of the G250 MAb in hypoxic tumours other than RCCs.

\section{Acknowledgements}

This study was supported by WILEX AG, and by the Slovak Scientific Grant Agency VEGA (2/0134/12 and 2/0081/14). There are the following potential conflicts of interest: i) the authors J. Pastorek, S. Pastorekova, and M. Zatovicova are inventors of patents related to CA IX; and ii) the study was partly funded by WILEX AG company, reputation of which may be affected by the publication of the study and the authors W. Schmalix, V. Boettger, P. Bevan are employees of that company.

\section{References}

1. Pastorekova S, Parkkila S, Pastorek J and Supuran CT: Carbonic anhydrases: current state of the art, therapeutic applications and future prospects. J Enzyme Inhib Med Chem 19: 199-229, 2004.

2. Pastoreková S, Parkkila S, Parkkila AK, Opavský R, Zelník V, Saarnio J and Pastorek J: Carbonic anhydrase IX, MN/CA IX: analysis of stomach complementary DNA sequence and expression in human and rat alimentary tracts. Gastroenterology 112: 398-408, 1997.

3. Pastorekova S, Parkkila S and Zavada J: Tumor-associated carbonic anhydrases and their clinical significance. Adv Clin Chem 42: 167-216, 2006.

4. Mandriota SJ, Turner KJ, Davies DR, Murray PG, Morgan NV, Sowter HM, Wykoff CC, Maher ER, Harris AL, Ratcliffe PJ and Maxwell PH: HIF activation identifies early lesions in VHL kidneys: evidence for site-specific tumor suppressor function in the nephron. Cancer Cell 1: 459-468, 2002.

5. Potter $\mathrm{C}$ and Harris AL: Hypoxia inducible carbonic anhydrase IX, marker of tumour hypoxia, survival pathway and therapy target. Cell Cycle 3: 164-167, 2004.

6. Wykoff CC, Beasley NJ, Watson PH, Turner KJ, Pastorek J, Sibtain A, Wilson GD, Turley H, Talks KL, Maxwell PH, et al: Hypoxia-inducible regulation of tumor-associated carbonic anhydrases. Cancer Res 60: 7075-7083, 2000.

7. Svastová E, Hulíková A, Rafajová M, Zat'ovicová M, Gibadulinová A, Casini A, Cecchi A, Scozzafava A, Supuran CT, Pastorek J and Pastoreková S: Hypoxia activates the capacity of tumour-associated carbonic anhydrase IX to acidify extracellular pH. FEBS Lett 577: 439-445, 2004.

8. Ditte P,Dequiedt F, Svastova E,Hulikova A,Ohradanova-Repic A, Zatovicova M, Csaderova L, Kopacek J, Supuran CT, Pastorekova S and Pastorek J: Phosphorylation of carbonic anhydrase IX controls its ability to mediate extracellular acidification in hypoxic tumors. Cancer Res 71: 7558-7567, 2011.

9. Dorai T, Sawczuk IS, Pastorek J, Wiernik PH and Dutcher JP: The role of carbonic anhydrase IX overexpression in kidney cancer. Eur J Cancer 41: 2935-2947, 2005.

10. Chiche J, Ilc K, Laferrière J, Trottier E, Dayan F, Mazure NM, Brahimi-Horn MC and Pouysségur J: Hypoxia-inducible carbonic anhydrase IX and XII promote tumour cell growth by counteracting acidosis through the regulation of the intracellular pH. Cancer Res 69: 358-368, 2009.

11. Dubois L, Peeters S, Lieuwes NG, Geusens N, Thiry A, Wigfield S, Carta F, McIntyre A, Scozzafava A, Dogné JM, et al: Specific inhibition of carbonic anhydrase IX activity enhances the in vivo therapeutic effect of tumour irradiation. Radiother Oncol 99: 424-431, 2011.

12. McIntyre A, Patiar S, Wigfield S, Li JL, Ledaki I, Turley H, Leek R, Snell C, Gatter K, Sly WS, et al: Carbonic anhydrase IX promotes tumour growth and necrosis in vivo and inhibition enhances anti-VEGF therapy. Clin Cancer Res 18: 3100-3111, 2012.

13. Svastová E, Zilka N, Zat'ovicová M, Gibadulinová A, Ciampor F, Pastorek J and Pastoreková S: Carbonic anhydrase IX reduces E-cadherin-mediated adhesion of MDCK cells via interaction with beta-catenin. Exp Cell Res 290: 332-345, 2003.

14. Svastova E, Witarski W, Csaderova L, Kosik I, Skvarkova L, Hulikova A, Zatovicova M, Barathova M, Kopacek J, Pastorek J and Pastorekova S: Carbonic anhydrase IX interacts with bicarbonate transporters in lamellipodia and increases cell migration via its catalytic domain. J Biol Chem 287: 3392-3402, 2012.

15. Csaderova L, Debreova M, Radvak P, Stano M, Vrestiakova M, Kopacek J, Pastorekova S and Svastova E: The effect of carbonic anhydrase IX on focal contacts during cell spreading and migration. Front Physiol 4: 271, 2013.

16. Závada J, Závadová Z, Pastoreková S, Ciampor F, Pastorek J and Zelník V: Expression of MaTu-MN protein in human tumor cultures and in clinical specimens. Int $\mathrm{J}$ Cancer 54: 268-274, 1993. 
17. Zatovicova M, Jelenska L, Hulikova A, Csaderova L, Ditte Z, Ditte P, Goliasova T, Pastorek J and Pastorekova S: Carbonic anhydrase IX as an anticancer therapy target: preclinical evaluation of internalizing monoclonal antibody directed to catalytic domain. Curr Pharm Des 16: 3255-3263, 2010.

18. Lou Y, McDonald PC, Oloumi A, Chia S, Ostlund C, Ahmadi A, Kyle A, Auf dem Keller U, Leung S, Huntsman D, et al: Targeting tumor hypoxia: suppression of breast tumour growth and metastasis by novel carbonic anhydrase IX inhibitors. Cancer Res 71: 3364-3376, 2011.

19. Rafajová M, Zatovicová M, Kettmann R, Pastorek J and Pastoreková S: Induction by hypoxia combined with low glucose or low bicarbonate and high posttranslational stability upon reoxygenation contribute to carbonic anhydrase IX expression in cancer cells. Int J Oncol 24: 995-1004, 2004.

20. Zatovicova M, Sedlakova O, Svastova E, Ohradanova A, Ciampor F, Arribas J, Pastorek J and Pastorekova S: Ectodomain shedding of the hypoxia-induced carbonic anhydrase IX is a metalloprotease-dependent process regulated by TACE/ADAM17. Br J Cancer 93: 1267-1276, 2005.

21. Zatovičová M and Pastorekova S: Modulation of cell surface density of carbonic anhydrase IX by shedding of the ectodomain and endocytosis. Acta Virol 57: 257-264, 2013.

22. Oosterwijk E, Ruiter DJ, Hoedemaeker PJ, Pauwels EK, Jonas U, Zwartendijk J and Warnaar SO: Monoclonal antibody G 250 recognizes a determinant present in renal-cell carcinoma and absent from normal kidney. Int J Cancer 38: 489-494, 1986.

23. Oosterwijk-Wakka JC, Boerman OC, Mulders PF and Oosterwijk E: Application of monoclonal antibody G250 recognizing carbonic anhydrase IX in renal cell carcinoma. Int J Mol Sci 14: 11402-11423, 2013.

24. Zat'ovicová M, Tarábková K, Svastová E, Gibadulinová A, Mucha V, Jakubícková L, Biesová Z, Rafajová M, Ortova Gut M, Parkkila S, et al: Monoclonal antibodies generated in carbonic anhydrase IX-deficient mice recognize different domains of tumour-associated hypoxia-induced carbonic anhydrase IX. J Immunol Methods 282: 117-134, 2003.

25. Pastorek J and Pastorekova S: Molecular mechanisms regulating expression and function of cancer-associated anhydrase IX. In The Tumour Microenvironment. Bagley RG (ed). Springer New York: Humana Press, NY, pp59-90, 2010.

26. Xu C, Lo A, Yammanuru A, Tallarico AS, Brady K, Murakami A, Barteneva N, Zhu Q and Marasco WA: Unique biological properties of catalytic domain directed human anti-CAIX antibodies discovered through phage-display technology. PLoS One 5: e9625, 2010

27. Murri-Plesko MT, Hulikova A, Oosterwijk E, Scott AM, Zortea A, Harris AL, Ritter G, Old L, Bauer S, Swietach P and Renner C: Antibody inhibiting enzymatic activity of tumour-associated carbonic anhydrase isoform IX. Eur J Pharmacol 657: 173-183, 2011.

28. Supuran CT: Carbonic anhydrases: novel therapeutic applications for inhibitors and activators. Nat Rev Drug Discov 7: $168-181,2008$.

29. Gnarra JR, Tory K, Weng Y, Schmidt L, Wei MH, Li H, Latif F, Liu S, Chen F, Duh FM, et al: Mutations of the VHL tumour suppressor gene in renal carcinoma. Nat Genet 7 : $85-90,1994$.

30. Ivanov SV, Kuzmin I, Wei MH, Pack S, Geil L, Johnson BE, Stanbridge EJ and Lerman MI: Down-regulation of transmembrane carbonic anhydrases in renal cell carcinoma cell lines by wild-type von Hippel-Lindau transgenes. Proc Natl Acad Sci USA 95: 12596-12601, 1998.

31. Wiesener MS, Münchenhagen PM, Berger I, Morgan NV, Roigas J, Schwiertz A, Jürgensen JS, Gruber G, Maxwell PH, Löning SA, et al: Constitutive activation of hypoxia-inducible genes related to overexpression of hypoxia-inducible factor-1alpha in clear cell renal carcinomas. Cancer Res 61: 5215-5222, 2001

32. Raval RR, Lau KW, Tran MGB, Sowter HM, Mandriota SJ, Li JL, Pugh CW, Maxwell PH, Harris AL and Ratcliffe PJ: Contrasting properties of hypoxia-inducible factor 1 (HIF-1) and HIF-2 in von Hippel-Lindau-associated renal cell carcinoma. Mol Cell Biol 25: 5675-5686, 2005.

33. Bui MH, Seligson D, Han KR, Pantuck AJ, Dorey FJ, Huang Y, Horvath S, Leibovich BC, Chopra S, Liao SY, et al: Carbonic anhydrase IX is an independent predictor of survival in advanced renal clear cell carcinoma: implications for prognosis and therapy. Clin Cancer Res 9: 802-811, 2003.
34. Brouwers AH, Frielink C, Oosterwijk E, Oyen WJ, Corstens FH and Boerman OC: Interferons can upregulate the expression of the tumor associated antigen G250-MN/CA IX, a potential target for (radio)immunotherapy of renal cell carcinoma. Cancer Biother Radiopharm 18: 539-547, 2003.

35. Atkins M, Regan M, McDermott D, Mier J, Stanbridge E, Youmans A, Febbo P, Upton M, Lechpammer M and Signoretti S: Carbonic anhydrase IX expression predicts outcome of interleukin 2 therapy for renal cancer. Clin Cancer Res 11: 3714-3721, 2005.

36. Chrastina A, Závada J, Parkkila S, Kaluz S, Kaluzová M, Rajcáni J, Pastorek J and Pastoreková S: Biodistribution and pharmacokinetics of 125I-labeled monoclonal antibody M75 specific for carbonic anhydrase IX, an intrinsic marker of hypoxia, in nude mice xenografted with human colorectal carcinoma. Int J Cancer 105: 873-881, 2003

37. Pastorek J, Pastoreková S, Callebaut I, Mornon JP, Zelník V, Opavský R, Zat'ovicová M, Liao S, Portetelle D, Stanbridge EJ, et al: Cloning and characterization of MN, a human tumor-associated protein with a domain homologous to carbonic anhydrase and a putative helix-loop-helix DNA binding segment. Oncogene 9: 2877-2888, 1994.

38. Grabmaier K, Vissers JL, De Weijert MC, Oosterwijk-Wakka JC, Van Bokhoven A, Brakenhoff RH, Noessner E, Mulders PA, Merkx G, Figdor CG, et al: Molecular cloning and immunogenicity of renal cell carcinoma-associated antigen G250. Int J Cancer 85: 865-870, 2000.

39. Oosterwijk E, Bander NH, Divgi CR, Welt S, Wakka JC, Finn RD, Carswell EA, Larson SM, Warnaar SO, Fleuren GJ, et al: Antibody localization in human renal cell carcinoma: a phase I study of monoclonal antibody G250. J Clin Oncol 11: 738-750, 1993.

40. Steffens MG, Boerman OC, Oosterwijk-Wakka JC, Oosterhof GO, Witjes JA, Koenders EB, Oyen WJ, Buijs WC, Debruyne FM, Corstens FH and Oosterwijk E: Targeting of renal cell carcinoma with iodine-131-labeled chimeric monoclonal antibody G250. J Clin Oncol 15: 1529-1537, 1997.

41. Bleumer I, Knuth A, Oosterwijk E, Hofmann R, Varga Z, Lamers C, Kruit W, Melchior S, Mala C, Ullrich S, et al: A phase II trial of chimeric monoclonal antibody G250 for advanced renal cell carcinoma patients. Br J Cancer 90: 985-990, 2004

42. Bleumer I, Oosterwijk E, Oosterwijk-Wakka JC, Völler MC, Melchior S, Warnaar SO, Mala C, Beck J and Mulders PF: A clinical trial with chimeric monoclonal antibody WX-G250 and low dose interleukin-2 pulsing scheme for advanced renal cell carcinoma. J Urol 175: 57-62, 2006.

43. Siebels M, Rohrmann K, Oberneder R, Stahler M, Haseke N, Beck J, Hofmann R, Kindler M, Kloepfer P and Stief C: A clinical phase I/II trial with the monoclonal antibody cG250 (RENCAREX ${ }^{\circledR}$ ) and interferon-alpha-2a in metastatic renal cell carcinoma patients. World J Urol 29: 121-126, 2011.

44. Belldegrun AS, Chamie K, Kloepfer P, Fall B, Bevan P, Störkel S, Wilhelm $\mathrm{O}$ and Pantuck AJ: ARISER: a randomized double blind phase III study to evaluate adjuvant cG250 treatment versus placebo in patients with high-risk ccRCC - results and implications for adjuvant clinical trials. J Clin Oncol 31 (Suppl; abs. $\left.4507^{\wedge}\right), 2013$.

45. Takacova M, Barathova M, Hulikova A, Ohradanova A, Kopacek J, Parkkila S, Pastorek J, Pastorekova S and Zatovicova M: Hypoxia-inducible expression of the mouse carbonic anhydrase IX demonstrated by new monoclonal antibodies. Int J Oncol 31: 1103-1110, 2007.

46. Barathova M, Takacova M, Holotnakova T, Gibadulinova A, Ohradanova A, Zatovicova M, Hulikova A, Kopacek J, Parkkila S, Supuran CT, et al: Alternative splicing variant of the hypoxia marker carbonic anhydrase IX expressed independently of hypoxia and tumour phenotype. Br J Cancer 98: 129-136, 2008.

47. Závada J, Závadová Z, Zat'ovicová M, Hyrsl L and Kawaciuk I: Soluble form of carbonic anhydrase IX (CA IX) in the serum and urine of renal carcinoma patients. Br J Cancer 89: 1067-1071, 2003.

48. Hyrsl L, Zavada J,Zavadova Z, Kawaciuk I, Vesely S and Skapa P: Soluble form of carbonic anhydrase IX (CAIX) in transitional cell carcinoma of urinary tract. Neoplasma 56: 298-302, 2009.

49. Zhou GX, Ireland J, Rayman P, Finke J and Zhou M: Quantification of carbonic anhydrase IX expression in serum and tissue of renal cell carcinoma patients using enzyme-linked immunosorbent assay: prognostic and diagnostic potentials. Urology 75: 257-261, 2010. 
50. Kock L, Mahner S, Choschzick M, Eulenburg C, Milde-Langosch K, Schwarz J, Jaenicke F, Müller V and Woelber L: Serum carbonic anhydrase IX and its prognostic relevance in vulvar cancer. Int $\mathrm{J}$ Gynecol Cancer 21: 141-148, 2011.

51. Müller V, Riethdorf S, Rack B, Janni W, Fasching PA, Solomayer E, Aktas B, Kasimir-Bauer S, Zeitz J, Pantel K, et al: Prospective evaluation of serum tissue inhibitor of metalloproteinase 1 and carbonic anhydrase IX in correlation to circulating tumor cells in patients with metastatic breast cancer. Breast Cancer Res 13: R71, 2011.

52. Gigante M, Li G, Ferlay C, Perol D, Blanc E, Paul S, Zhao A, Tostain J, Escudier B, Negrier S and Genin C: Prognostic value of serum CA9 in patients with metastatic clear cell renal cell carcinoma under targeted therapy. Anticancer Res 32: 5447-5451, 2012

53. Takacova M, Bartosova M, Skvarkova L, Zatovicova M Vidlickova I, Csaderova L, Barathova M, Breza J Jr, Bujdak P, Pastorek J, et al: Carbonic anhydrase IX is a clinically significant tissue and serum biomarker associated with renal cell carcinoma. Oncol Lett 5: 191-197, 2013.

54. Alterio V, Hilvo M, Di Fiore A, Supuran CT, Pan P, Parkkila S, Scaloni A, Pastorek J, Pastorekova S, Pedone C, et al: Crystal structure of the catalytic domain of the tumor-associated human carbonic anhydrase IX. Proc Natl Acad Sci USA 106: 16233-16238, 2009.

55. Dubois L, Lieuwes NG, Maresca A, Thiry A, Supuran CT Scozzafava A, Wouters BG and Lambin P: Imaging of CA IX with fluorescent labelled sulfonamides distinguishes hypoxic and (re)-oxygenated cells in a xenograft tumour model. Radiother Oncol 92: 423-428, 2009

56. Dürrbach A, Angevin E, Poncet P, Rouleau M, Chavanel G Chapel A, Thierry D, Gorter A, Hirsch R, Charpentier B, et al: Antibody-mediated endocytosis of G250 tumor-associated antigen allows targeted gene transfer to human renal cell carcinoma in vitro. Cancer Gene Ther 6: 564-571, 1999.

57. Grantab R, Sivananthan S and Tannock IF: The penetration of anticancer drugs through tumour tissue as a function of cellular adhesion and packing density of tumour cells. Cancer Res 66: 1033-1039, 2006

58. Sorkin A and von Zastrow M: Endocytosis and signalling: intertwining molecular networks. Nat Rev Mol Cell Biol 10: $609-622,2009$
59. Surfus JE, Hank JA, Oosterwijk E, Welt S, Lindstrom MJ, Albertini MR, Schiller JH and Sondel PM: Anti-renal-cell carcinoma chimeric antibody $\mathrm{G} 250$ facilitates antibodydependent cellular cytotoxicity with in vitro and in vivo interleukin-2-activated effectors. J Immunother Emphasis Tumor Immunol 19: 184-191, 1996.

60. Liu Z, Smyth FE, Renner C, Lee FT, Oosterwijk E and Scott AM: Anti-renal cell carcinoma chimeric antibody G250: cytokine enhancement of in vitro antibody-dependent cellular cytotoxicity. Cancer Immunol Immunother 51: 171-177, 2002.

61. Divgi CR, Pandit-Taskar N, Jungbluth AA, Reuter VE, Gönen M, Ruan S, Pierre C, Nagel A, Pryma DA, Humm J, et al: Preoperative characterisation of clear-cell renal carcinoma using iodine-124-labelled antibody chimeric G250 ( $\left.{ }^{124} \mathrm{I}-\mathrm{cG} 250\right)$ and PET in patients with renal masses: a phase I trial. Lancet Oncol 8: 304-310, 2007.

62. Beasley NJ, Wykoff CC, Watson PH, Leek R, Turley H, Gatter K, Pastorek J, Cox GJ, Ratcliffe P and Harris AL: Carbonic anhydrase IX, an endogenous hypoxia marker, expression in head and neck squamous cell carcinoma and its relationship to hypoxia, necrosis and microvessel density. Cancer Res 61: 5262-5267, 2001.

63. Turner KJ, Crew JP, Wykoff CC, Watson PH, Poulsom R, Pastorek J, Ratcliffe PJ, Cranston D and Harris AL: The hypoxia-inducible genes VEGF and CA9 are differentially regulated in superficial vs invasive bladder cancer. $\mathrm{Br} J$ Cancer 86: 1276-1282, 2002.

64. Swinson DE, Jones JL, Cox G, Richardson D, Harris AL and O'Byrne KJ: Hypoxia-inducible factor-1 alpha in non small cell lung cancer: relation to growth factor, protease and apoptosis pathways. Int J Cancer 111: 43-50, 2004.

65. Harris AL: Hypoxia - a key regulatory factor in tumour growth. Nat Rev Cancer 2: 38-47, 2002.

66. Olive PL, Aquino-Parsons C, MacPhail SH, Laio S, Raleigh JA, Lerman MI and Stanbridge EJ: Carbonic anhydrase 9 as an endogenous marker for hypoxic cells in cervical cancer. Cancer Res 61: 8924-8929, 2001.

67. Thiery JP and Sleeman JP: Complex networks orchestrate epithelial-mesenchymal transitions. Nat Rev Mol Cell Biol 7: 131-142, 2006. 